Check for updates

Cite this: RSC Adv., 2019, 9, 9235

\title{
Xylopins $A-F$, six rare guaiane dimers with three different connecting modes from Xylopia vielana $\uparrow$
}

\author{
Yang-Guo Xie,,$^{\mathrm{a}}$ Rong Yan,,$^{\mathrm{b}}$ Xianglong Zhong, ${ }^{\mathrm{d}}$ Huang Piao, ${ }^{\mathrm{b}}$ Ishaq Muhammad, ${ }^{\mathrm{a}}$ \\ Xisong Ke, ${ }^{b}$ Shikai Yan, ${ }^{a}$ Yuanqiang Guo, ${ }^{* e}$ Hui-Zi Jin (D) *ac and Wei-Dong Zhang*abc
}

Six rare guaiane-type sesquiterpene dimers xylopins $A-F$, having three different connecting modes through two direct $\mathrm{C}-\mathrm{C}$ bonds, were isolated from the roots of Xylopia vielana. Their absolute configurations were established by NOESY analysis, $\mathrm{Cu} \mathrm{K} \alpha \mathrm{X}$-ray crystallography, and experimental and calculated electronic circular dichroism spectra. Flow cytometry demonstrated the fact that compound 6 arrested the cell cycle at G2 phase and concentration-dependently induced apoptosis of DU145 cells. Furthermore, the EPT2TGC cell model, zebrafish study and western blot analysis illustrated compound 6 could induce apoptosis by efficiently inhibiting the $\mathrm{Wnt} / \beta$-catenin signaling pathway via decreasing the expression of $\beta$-catenin.

Received 15th January 2019

Accepted 4th March 2019

DOI: $10.1039 / c 9 r a 00347 a$

rsc.li/rsc-advances
Our ongoing natural-product-based screening studies on Wnt pathways have identified and successfully isolated xylopin F (6), a unique sesquiterpene dimer, which induces apoptosis in DU145 cells by Wnt signaling pathway. Herein, we described the isolation and structural elucidation of these compounds as well as a screening study of the isolated compounds on Wnt signaling pathways.

\section{Results and discussion}

Xylopin A (1) was obtained as colorless crystals. Its molecular formula $\mathrm{C}_{32} \mathrm{H}_{42} \mathrm{O}_{4}$ was established by HR-ESI: $m / z$ 513.2977 [M + $\mathrm{Na}]^{+}$(calcd for $\mathrm{C}_{32} \mathrm{H}_{42} \mathrm{O}_{4} \mathrm{Na}^{+}, 513.2975$ ), containing 12 degrees of unsaturation. The 1D-NMR spectra of 1 showed 32 carbon resonances including nine methyls, four methylenes, seven methines, and 12 quaternary carbons, implying the presence of two sesquiterpene units (1A and $1 \mathrm{~B})$. In unit $1 \mathrm{~A}$, the $\mathrm{HMBC}$ cross-peaks from $\mathrm{H}-3$ to $\mathrm{C}-1 / \mathrm{C}-5$ and from $\mathrm{H}_{3}-15$ to $\mathrm{C}-3 / \mathrm{C}-4 / \mathrm{C}-5$ suggested the appearance of a five-membered ring (I) (Fig. 2). Moreover, a seven-membered (II) was fused with five-membered ring (I) at C- 1 and C- 5 by analyses of the HMBC cross-peaks from

${ }^{a}$ Shanghai Key Laboratory for Molecular Engineering of Chiral Drugs, School of Pharmacy, Shanghai Jiao Tong University, Shanghai 200240, China. E-mail: wdzhangy@hotmail.com; kimhz@sjtu.edu.cn; Fax: +86-21-34205989; Tel: +86-2134205989

${ }^{b}$ Institute of Interdisciplinary Sciences, Shanghai University of Tradictional Chinese Medicine, Shanghai 201203, China

'School of Pharmacy, Second Military Medical University, Shanghai, 200433, China

${ }^{d}$ Department of Pharmacy, Anhui University of Chinese Medicine, Hefei 320000, P. R. China

${ }^{e}$ State Key Laboratory of Medicinal Chemical Biology, College of Pharmacy, Tianjin Key Laboratory of Molecular Drug Research, Nankai University, Tianjin 300350, People's Republic of China. E-mail: victgyq@nankai.edu.cn

$\dagger$ Electronic supplementary information (ESI) available. CCDC 1834120, 1840033 and 1841412. For ESI and crystallographic data in CIF or other electronic format see DOI: $10.1039 / \mathrm{c} 9 \mathrm{ra} 00347 \mathrm{a}$

\$ These authors contributed equally.
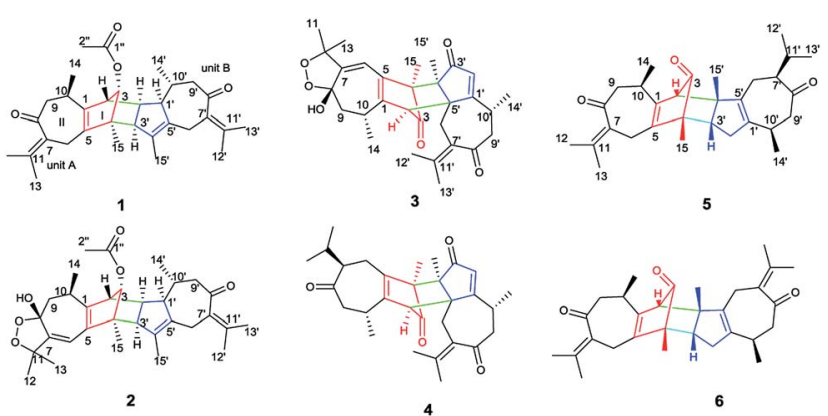

Fig. 1 Chemical structure of 1-6 


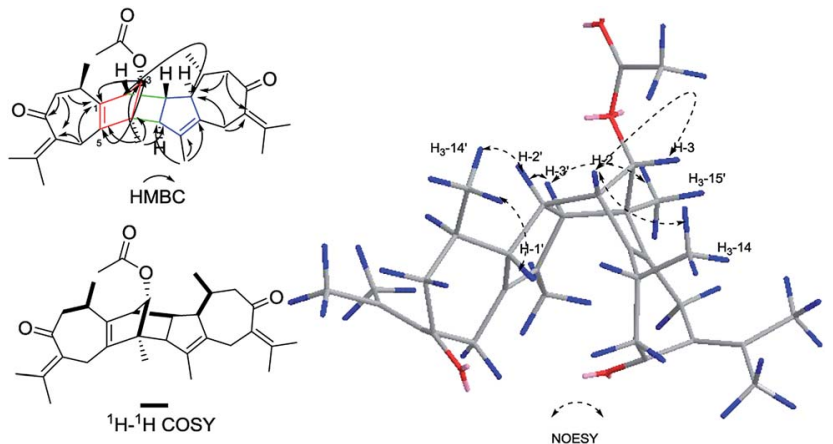

Fig. 2 Key HMBC, ${ }^{1} \mathrm{H}-{ }^{1} \mathrm{H}$ COSY and NOESY correlations of 1.

$\mathrm{H}_{2}-6$ to $\mathrm{C}-1 / \mathrm{C}-7 / \mathrm{C}-5$, from $\mathrm{H}-10$ to $\mathrm{C}-1 / \mathrm{C}-8 / \mathrm{C}-9$ and from $\mathrm{H}_{2}-9$ to C-1/C-8/C-10 (Fig. 2). Additionally, the HMBC cross-peaks from $\mathrm{H}_{3}-12$ to $\mathrm{C}-7 / \mathrm{C}-11$ and from $\mathrm{H}_{3}-13$ to $\mathrm{C}-7 / \mathrm{C}-11$ indicated that a methylethylidene group was connected to ring (II) at the C-7 (Fig. 2). On the basis of the above spectral analysis, the unit $1 \mathrm{~A}$ was established as a guaiane unit. Similarly, unit 1B was also assigned as a guaiane unit due to the aid of key HMBC crosspeaks from $\mathrm{H}_{2}-6^{\prime}$ to $\mathrm{C}-1^{\prime} / \mathrm{C}-7^{\prime} / \mathrm{C}-5^{\prime}, \mathrm{H}-10^{\prime}$ to $\mathrm{C}-1^{\prime} / \mathrm{C}-8^{\prime} / \mathrm{C}-9^{\prime}$ and $\mathrm{H}_{2}-9^{\prime}$ to $\mathrm{C}-1^{\prime} / \mathrm{C}-8^{\prime} / \mathrm{C}-10^{\prime}$ (Fig. 2). Therefore, 1 was elucidated as a dimeric guaiane. The linkage of unit $1 \mathrm{~A}$ and unit $1 \mathrm{~B}$ via two direct $\mathrm{C}-\mathrm{C}$ bonds (C-2 to $\mathrm{C}-2^{\prime}, \mathrm{C}-4$ to $\mathrm{C}-3^{\prime}$ ) was deduced from the key HMBC cross-peaks from $\mathrm{H}_{3}-15$ to $\mathrm{C}-3^{\prime}, \mathrm{H}-2$ to $\mathrm{C}-2^{\prime}$ and from $\mathrm{H}-\mathbf{1}^{\prime}$ to $\mathrm{C}-2$ (Fig. 2). Thus, the planar structure of $\mathbf{1}$ was confirmed by the above detailed analyses of NMR data. The relative configuration of $\mathbf{1}$ was deduced from the observed NOESY correlations. The key NOESY correlations of $\mathrm{H}_{3}-14 / \mathrm{H}-2$ indicated they were in the same face and assigned as $\beta$ oriented (Fig. 2), while the correlations of $\mathrm{H}-2^{\prime} / \mathrm{H}_{3}-14^{\prime}, \mathrm{H}-1^{\prime} / \mathrm{H}_{3}-$ $14^{\prime}$ and $\mathrm{H}-3^{\prime} / \mathrm{H}_{3}-15$ placed them on the opposite side and assigned as $\alpha$-oriented (Fig. 2). Finally, the absolute configuration was determined necessary to by a $\mathrm{Cu} \mathrm{K} \alpha \mathrm{X}$-ray diffraction experiment and assigned as $2 S, 3 S, 4 R, 10 R, 1^{\prime} R, 2^{\prime} R, 3^{\prime} R, 10^{\prime} R$ (Fig. 3).

Xylopin B (2) showed the $[\mathrm{M}+\mathrm{Na}]^{+}$peak at $m / z 545.2876$ by HRESI-MS (calcd 545.2874), consistent with the molecular formula $\mathrm{C}_{32} \mathrm{H}_{42} \mathrm{O}_{6}$. Comprehensive NMR data analysis of 2

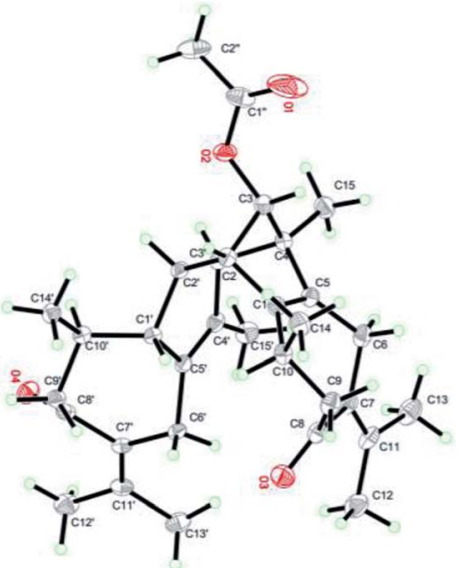

Fig. 3 X-ray structure of 1 . displayed the presence of two guaiane units, which revealed its structural similarity to 1 except for the existence an another penta-ring at unit $2 \mathrm{~A}$. Interestingly, the chemical shift of C-8 $\left(\delta_{\mathrm{C}}\right.$ 102.8) and C-11 $\left(\delta_{\mathrm{C}} 85.4\right)$ indicated that the five-membered ring involved a peroxide group between the $\mathrm{C}-8$ and $\mathrm{C}-11$ (Table 1 ). In unit 2A, the key HMBC correlation from $\mathrm{H}-6$ to $\mathrm{C}-7 / \mathrm{C}-8, \mathrm{H}_{3}-12$ to C-11/C-7 and $\mathrm{H}_{3}-13$ to C-11/C-7 verified that the five-membered ring was connected to seven-membered ring at C-7 and C-8 (Fig. 4). The two units $2 \mathrm{~A}$ and $2 \mathrm{~B}$ were linked through two direct $\mathrm{C}-\mathrm{C}$ bonds $\left(\mathrm{C}-2\right.$ to $\mathrm{C}-2^{\prime}, \mathrm{C}-4$ to $\left.\mathrm{C}-3^{\prime}\right)$ on the basis of the key HMBC correlation from $\mathrm{H}_{3}-15$ to $\mathrm{C}-3^{\prime}$, and $\mathrm{H}-2$ to $\mathrm{C}-2^{\prime}$ (Fig. 4). The relative configuration of 2 was identical with 1 regarding with the same NOESY correlation. The stereochemistry of 2 was unambiguously determined by X-ray crystallography using $\mathrm{Cu}$ $\mathrm{K} \alpha$ radiation as $2 S, 3 S, 4 R, 8 S, 10 R, 1^{\prime} R, 2^{\prime} R, 3^{\prime} R, 10^{\prime} R$ (Fig. 5).

Xylopin C (3) exhibited a $[\mathrm{M}+\mathrm{Na}]^{+}$ion peak at $\mathrm{m} / \mathrm{z} 515.2418$ (calcd for 515.2404), with colorless crystals, ascribe to the molecular formula $\mathrm{C}_{30} \mathrm{H}_{36} \mathrm{O}_{6}$. Eight methyl groups, three

Table $1{ }^{1} \mathrm{H}$ and ${ }^{13} \mathrm{C}$ NMR spectroscopic data of 1 and $2^{a}$

\begin{tabular}{|c|c|c|c|c|}
\hline \multirow[b]{2}{*}{ No. } & \multicolumn{2}{|l|}{1} & \multicolumn{2}{|l|}{2} \\
\hline & $\delta_{\mathrm{C}}$ & $\delta_{\mathrm{H}}$ & $\delta_{\mathrm{C}}$ & $\delta_{\mathrm{H}}$ \\
\hline 1 & $140.2 \mathrm{~s}$ & & $146.7 \mathrm{~s}$ & \\
\hline 2 & $49.0 \mathrm{~d}$ & $2.60 \mathrm{dd}(4.5,1.9)$ & $50.1 \mathrm{~d}$ & $2.92 \mathrm{dd}(4.6,2.0)$ \\
\hline 3 & $86.7 \mathrm{~d}$ & $4.21 \mathrm{~d}(2.0)$ & $86.0 \mathrm{~d}$ & $4.27 \mathrm{~d}(1.9)$ \\
\hline 4 & $57.4 \mathrm{~s}$ & & $55.5 \mathrm{~s}$ & \\
\hline 5 & $136.6 \mathrm{~s}$ & & $131.3 \mathrm{~s}$ & \\
\hline 6 & $25.8 \mathrm{t}$ & $\begin{array}{l}3.14 \mathrm{~d}(17.0) \\
2.70 \mathrm{~m}\end{array}$ & $112.2 \mathrm{~d}$ & $5.49 \mathrm{~s}$ \\
\hline 7 & $134.5 \mathrm{~s}$ & & $154.9 \mathrm{~s}$ & \\
\hline 8 & $203.9 \mathrm{~s}$ & & $103.6 \mathrm{~s}$ & \\
\hline 9 & $48.1 \mathrm{t}$ & $\begin{array}{l}2.68 \\
2.54 \mathrm{dd}(12.3,4.5)\end{array}$ & $38.7 \mathrm{t}$ & $\begin{array}{l}2.10 \mathrm{dd}(13.6,5.7) \\
1.69 \mathrm{t}(13.1)\end{array}$ \\
\hline $\begin{array}{l}10 \\
11\end{array}$ & $\begin{array}{l}35.3 \mathrm{~d} \\
139.8 \mathrm{~s}\end{array}$ & $2.47 \mathrm{~m}$ & $\begin{array}{l}33.2 \mathrm{~d} \\
85.3 \mathrm{~s}\end{array}$ & $2.76 \mathrm{~m}$ \\
\hline 12 & $22.7 \mathrm{q}$ & $1.97 \mathrm{~s}$ & $24.7 \mathrm{q}$ & $1.43 \mathrm{~s}$ \\
\hline 13 & $22.8 \mathrm{q}$ & $1.79 \mathrm{~s}$ & $27.4 \mathrm{q}$ & $1.41 \mathrm{~s}$ \\
\hline 14 & $20.0 \mathrm{q}$ & $1.08 \mathrm{~d}(6.9)$ & $19.1 \mathrm{q}$ & $1.24 \mathrm{~d}(7.1)$ \\
\hline 15 & $14.7 \mathrm{q}$ & $1.22 \mathrm{~s}$ & $14.7 \mathrm{q}$ & $1.28 \mathrm{~s}$ \\
\hline $1^{\prime}$ & $57.3 \mathrm{~d}$ & $1.64 \mathrm{~m}$ & $57.4 \mathrm{~d}$ & $1.85 \mathrm{~m}$ \\
\hline $2^{\prime}$ & $48.0 \mathrm{~d}$ & $2.32 \mathrm{~m}$ & $48.5 \mathrm{~d}$ & $2.42 \mathrm{~m}$ \\
\hline $3^{\prime}$ & $59.1 \mathrm{~d}$ & $2.79 \mathrm{~d}(8.0)$ & $58.8 \mathrm{~d}$ & $2.86 \mathrm{~d}(8.0)$ \\
\hline $4^{\prime}$ & $134.6 \mathrm{~s}$ & & $134.4 \mathrm{~s}$ & \\
\hline $5^{\prime}$ & $138.2 \mathrm{~s}$ & & $138.3 \mathrm{~s}$ & \\
\hline $6^{\prime}$ & $28.2 \mathrm{t}$ & $\begin{array}{l}3.23 \mathrm{~d}(15.7) \\
2.66 \mathrm{dd}(9.9,7.4)\end{array}$ & $28.4 \mathrm{t}$ & $\begin{array}{l}3.23 \mathrm{~d}(15.1) \\
2.61 \mathrm{~d}(15.1)\end{array}$ \\
\hline $7^{\prime}$ & $133.4 \mathrm{~s}$ & & $133.1 \mathrm{~s}$ & \\
\hline $8^{\prime}$ & $206.1 \mathrm{~s}$ & & $205.6 \mathrm{~s}$ & \\
\hline $9^{\prime}$ & $50.7 \mathrm{t}$ & $\begin{array}{l}2.66 \mathrm{dd}(9.9,7.4) \\
2.17 \mathrm{dd}(11.4,2.1)\end{array}$ & $50.9 \mathrm{t}$ & $\begin{array}{l}2.70 \mathrm{~d}(11.6) \\
2.20 \mathrm{dd}(11.6,1.9)\end{array}$ \\
\hline $\begin{array}{l}10^{\prime} \\
11^{\prime}\end{array}$ & $\begin{array}{l}41.3 \mathrm{~d} \\
138.2 \mathrm{~s}\end{array}$ & $1.36 \mathrm{~m}$ & $\begin{array}{l}41.2 \mathrm{~d} \\
140.4 \mathrm{~s}\end{array}$ & $1.44 \mathrm{~m}$ \\
\hline $12^{\prime}$ & $22.3 \mathrm{q}$ & $1.93 \mathrm{~s}$ & $22.5 \mathrm{q}$ & $1.96 \mathrm{~s}$ \\
\hline $13^{\prime}$ & $22.3 \mathrm{q}$ & $1.82 \mathrm{~s}$ & $22.0 \mathrm{q}$ & $1.83 \mathrm{~s}$ \\
\hline $14^{\prime}$ & $21.8 \mathrm{q}$ & $0.98 \mathrm{~d}(6.5)$ & $22.1 \mathrm{q}$ & $1.04 \mathrm{~d}(6.5)$ \\
\hline $15^{\prime}$ & $13.9 \mathrm{q}$ & $1.40 \mathrm{~d}(1.9)$ & $13.7 \mathrm{q}$ & $1.42 \mathrm{~s}$ \\
\hline $1^{\prime}$ & $170.8 \mathrm{~s}$ & & $170.8 \mathrm{~s}$ & \\
\hline $2^{\prime}$ & $21.1 \mathrm{q}$ & $2.02 \mathrm{~s}$ & $21.6 \mathrm{q}$ & $2.06 \mathrm{~s}$ \\
\hline
\end{tabular}

${ }^{a} \delta$ in ppm; $J$ in $\mathrm{Hz}$ within parentheses; measured at $125 \mathrm{MHz}$ for ${ }^{13} \mathrm{C}$ NMR and $500 \mathrm{MHz}$ for ${ }^{1} \mathrm{H}$ NMR in chloroform- $d$. 


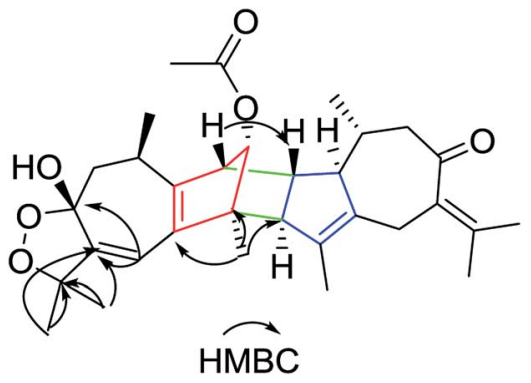

Fig. 4 Key HMBC correlations of 2.

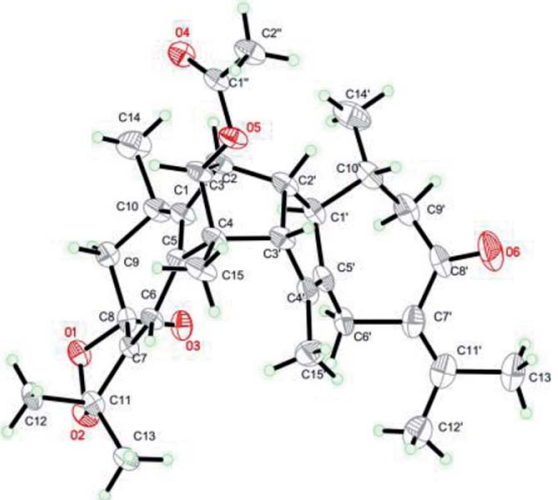

Fig. 5 X-ray structure of 2 .

methylene signals, five methines (two olefinic protons) were observed in the ${ }^{1} \mathrm{H}$ NMR spectrum (Table 2). The NMR data of 3 were similar to those of $\mathbf{2}$, suggesting $\mathbf{3}$ showed the presence of two guaiane units but with a different linkage. In addition, the acetoxy group at C-3 in $\mathbf{2}$ was replaced by the acetate group in 3 . The connection type of two units was via direct $\mathrm{C}-\mathrm{C}$ bonds (C-2 to $\mathrm{C}-5^{\prime}, \mathrm{C}-4$ to $\mathrm{C}-4^{\prime}$ ) due to the key HMBC correlations from $\mathrm{H}-2$ to $\mathrm{C}-5$, from $\mathrm{H}_{3}-15$ to $\mathrm{C}-4^{\prime}$ (Fig. 6). The $\alpha$-orientation at $\mathrm{H}_{3}-14, \mathrm{H}-$ 2, $\mathrm{H}_{3}-15$ and $\mathrm{H}_{3}-14^{\prime}$ were confirmed by the NOESY correlations from $\mathrm{H}_{3}-15 / \mathrm{H}_{3}-15^{\prime}, \mathrm{H}-2 / \mathrm{H}_{3}-14, \mathrm{H}-2 / \mathrm{H}_{3}-14^{\prime}$ and $\mathrm{H}-2 / \mathrm{H}_{3}-15^{\prime}$ (Fig. 6). The key NOESY correlations of $\mathrm{H}-2 / \mathrm{H}_{3}-15^{\prime}$ revealed that 3 was stacked arrangements of two sesquiterpene units A and B with endo-orientation. The absolute configuration of 3 was confirmed by a single-crystal X-ray diffraction analysis $(2 R, 4 S$, $8 S, 10 R, 4^{\prime} R, 5^{\prime} R, 10^{\prime} R$ ) (Fig. 7).

Xylopin D (4) had the molecular formula $\mathrm{C}_{30} \mathrm{H}_{38} \mathrm{O}_{4}$ as determined by the HRESIMS at $m / z 485.2670[\mathrm{M}+\mathrm{Na}]^{+}$(calcd for, 485.2662). Comprehensive interpretation of the 1D-NMR and 2D-NMR analysis of $\mathbf{4}$ were closely comparable to those of 3 except for the disappearance of the five-membered ring containing double oxygen bridge in unit $4 \mathrm{~A}$ (Table 2). The linkage mode was consistent with 3 owing to the same key HMBC correlations. Furthermore, in NOESY spectrum, the relative configuration of $\mathrm{H}-7$ was assigned as $\beta$-orientation on the basis of the correlation from $\mathrm{H}-7$ to $\mathrm{H}_{3}-15$ (Fig. 8). The key NOESY correlations of $\mathrm{H}-2 / \mathrm{H}_{3}-15^{\prime}$ indicated two guaiane units were endo-orientated. Thus, the absolute configuration of $\mathbf{4}$ was defined as $\left(2 R, 4 S, 7 S, 10 R, 4^{\prime} R, 5^{\prime} R, 10^{\prime} R\right)$ for the CD spectrum (Fig. S49†) matched well with the experimental result.
Table $2{ }^{1} \mathrm{H}$ and ${ }^{13} \mathrm{C}$ NMR spectroscopic data of 3 and $4^{a}$

\begin{tabular}{|c|c|c|c|c|}
\hline \multirow[b]{2}{*}{ No. } & \multicolumn{2}{|l|}{3} & \multicolumn{2}{|l|}{4} \\
\hline & $\delta_{\mathrm{C}}$ & $\delta_{\mathrm{H}}$ & $\delta_{\mathrm{C}}$ & $\delta_{\mathrm{H}}$ \\
\hline 1 & $143.4 \mathrm{~s}$ & & $140.6 \mathrm{~s}$ & \\
\hline 2 & $55.1 \mathrm{~d}$ & $3.19 \mathrm{~s}$ & $53.9 \mathrm{~d}$ & $2.91 \mathrm{~s}$ \\
\hline 3 & $200.7 \mathrm{~s}$ & & $200.1 \mathrm{~s}$ & \\
\hline 4 & $54.1 \mathrm{~s}$ & & $60.9 \mathrm{~s}$ & \\
\hline 5 & $131.2 \mathrm{~s}$ & & $138.1 \mathrm{~s}$ & \\
\hline 6 & $110.4 \mathrm{~d}$ & $5.40 \mathrm{~s}$ & $23.2 \mathrm{t}$ & $\begin{array}{l}2.44 \mathrm{dd}(13.3,3.4) \\
2.17 \mathrm{~m}\end{array}$ \\
\hline 7 & $157.2 \mathrm{~s}$ & & $59.2 \mathrm{~d}$ & $2.13 \mathrm{~m}$ \\
\hline 8 & $102.1 \mathrm{~s}$ & & $213.3 \mathrm{~s}$ & \\
\hline 9 & $38.2 \mathrm{t}$ & $\begin{array}{l}2.00 \mathrm{dd}(13.2,5.8) \\
1.60 \mathrm{t}(13.2)\end{array}$ & $46.6 \mathrm{t}$ & $\begin{array}{l}2.83 \mathrm{~d}(12.5) \\
2.19 \mathrm{~m}\end{array}$ \\
\hline 10 & $31.6 \mathrm{~d}$ & $2.58 \mathrm{~m}$ & $34.8 \mathrm{~d}$ & $2.20 \mathrm{~m}$ \\
\hline 11 & $85.6 \mathrm{~s}$ & & $31.1 \mathrm{~d}$ & $1.83 \mathrm{~m}$ \\
\hline 12 & $26.9 \mathrm{q}$ & $1.33 \mathrm{~s}$ & $20.3 \mathrm{q}$ & $0.89 \mathrm{~d}(6.6)$ \\
\hline 13 & $22.1 \mathrm{q}$ & $1.41 \mathrm{~s}$ & $20.1 \mathrm{q}$ & $0.88 \mathrm{~d}(6.6)$ \\
\hline 14 & $17.1 \mathrm{q}$ & $1.12 \mathrm{~d}(7.1)$ & $19.5 \mathrm{q}$ & $1.07 \mathrm{~d}(6.6)$ \\
\hline 15 & $7.2 \mathrm{q}$ & $1.30 \mathrm{~s}$ & $7.9 \mathrm{q}$ & $1.23 \mathrm{~s}$ \\
\hline $1^{\prime}$ & $184.2 \mathrm{~s}$ & & $183.5 \mathrm{~s}$ & \\
\hline $2^{\prime}$ & $131.2 \mathrm{~d}$ & $6.04 \mathrm{~d}(1.0)$ & $131.6 \mathrm{~d}$ & $6.05 \mathrm{~s}$ \\
\hline $3^{\prime}$ & $208.8 \mathrm{~s}$ & & $208.5 \mathrm{~s}$ & \\
\hline $4^{\prime}$ & $59.4 \mathrm{~s}$ & & $54.5 \mathrm{~s}$ & \\
\hline $5^{\prime}$ & $57.2 \mathrm{~s}$ & & $56.5 \mathrm{~s}$ & \\
\hline $6^{\prime}$ & $31.2 \mathrm{t}$ & $\begin{array}{l}2.59 \mathrm{~d}(15.0) \\
2.22 \mathrm{~d}(15.0)\end{array}$ & $31.2 \mathrm{t}$ & $\begin{array}{l}2.56 \mathrm{~d}(15.1) \\
2.21 \mathrm{~d}(15.1)\end{array}$ \\
\hline $7^{\prime}$ & $131.2 \mathrm{~s}$ & & $130.3 \mathrm{~s}$ & \\
\hline $8^{\prime}$ & $205.1 \mathrm{~s}$ & & $204.3 \mathrm{~s}$ & \\
\hline $9^{\prime}$ & $48.1 \mathrm{t}$ & $2.55 \mathrm{~m}$ & $49.5 \mathrm{t}$ & $2.53 \mathrm{~m}$ \\
\hline $10^{\prime}$ & $32.7 \mathrm{~d}$ & $2.53 \mathrm{~m}$ & $32.4 \mathrm{~d}$ & $2.43 \mathrm{~m}$ \\
\hline $11^{\prime}$ & $146.9 \mathrm{~s}$ & & $148.2 \mathrm{~s}$ & \\
\hline $12^{\prime}$ & $22.3 \mathrm{q}$ & $2.06 \mathrm{~s}$ & $23.9 \mathrm{q}$ & $2.06 \mathrm{~s}$ \\
\hline $13^{\prime}$ & $22.4 \mathrm{q}$ & $1.98 \mathrm{~s}$ & $23.4 \mathrm{q}$ & $1.95 \mathrm{~s}$ \\
\hline $14^{\prime}$ & $18.5 \mathrm{q}$ & $1.29 \mathrm{~d}(6.0)$ & $19.2 \mathrm{q}$ & $1.23 \mathrm{~d}(6.0)$ \\
\hline $15^{\prime}$ & $12.1 \mathrm{q}$ & $1.03 \mathrm{~s}$ & $13.4 \mathrm{q}$ & $1.01 \mathrm{~s}$ \\
\hline
\end{tabular}

${ }^{a} \delta$ in ppm; $J$ in $\mathrm{Hz}$ within parentheses; measured at $125 \mathrm{MHz}$ for ${ }^{13} \mathrm{C}$ NMR and $500 \mathrm{MHz}$ for ${ }^{1} \mathrm{H}$ NMR in chloroform- $d$.

Xylopin E (5) was obtained as yellow oil. Its molecular formula $\mathrm{C}_{30} \mathrm{H}_{40} \mathrm{O}_{3}$ was established by HR-ESI: $\mathrm{m} / z$ 471.2880 [M + $\mathrm{Na}]^{+}$(calcd for $\mathrm{C}_{30} \mathrm{H}_{40} \mathrm{O}_{3} \mathrm{Na}^{+}, 471.2870$ ), indicating 11 degrees of unsaturation. Careful analysis of the ${ }^{13} \mathrm{C}$ NMR and DEPT spectrum showed 30 carbon signals, comprising eight methyls, five methylenes, six methines and 11 quaternary carbons (Table 3). Combined with 2D-NMR, 5 displayed the presence of two asymmetry guaiane units (5A and $5 \mathrm{~B})$. Unit $5 \mathrm{~A}$ was highly similar with unit $1 \mathrm{~A}$ except for the presence of the carbonyl group at C-3 instead of the acetate group, while unit 5B was in

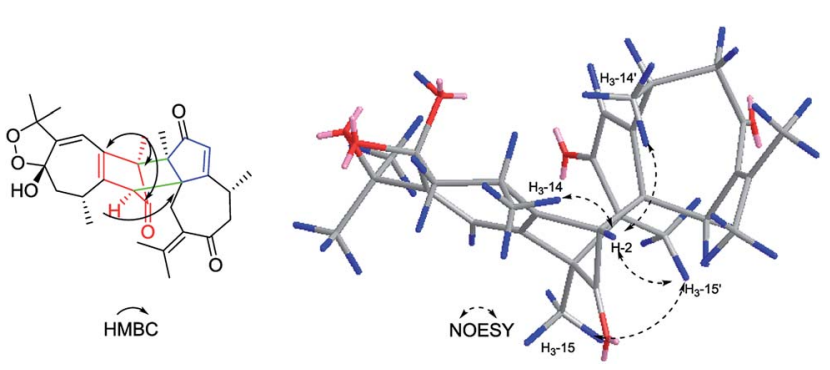

Fig. 6 Key HMBC and NOESY correlations of 3. 


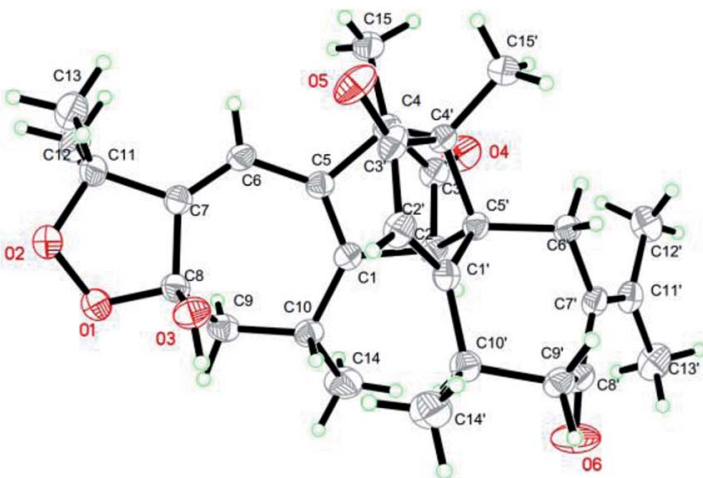

Fig. 7 X-ray structure of 3 .

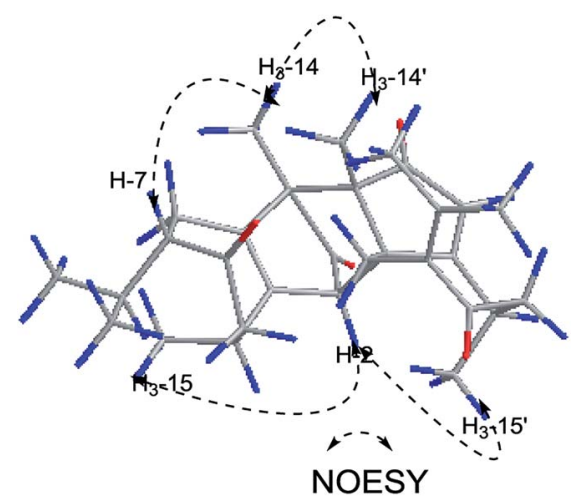

Fig. 8 Key HMBC and NOESY correlations of 4.

good agreement with unit $1 \mathrm{~A}$ except for the presence of the carbonyl group at $\mathrm{C}-3$. The linkage of units $5 \mathrm{~A}$ and unit $5 \mathrm{~B}$ via two direct $\mathrm{C}-\mathrm{C}$ bonds (C-2 to $\mathrm{C}-4^{\prime}, \mathrm{C}-4$ to $\mathrm{C}-3^{\prime}$ ) was deduced from the key HMBC cross-peaks from $\mathrm{H}-3^{\prime}$ to $\mathrm{C}-4, \mathrm{H}_{3}-15^{\prime}$ to $\mathrm{C}-2$ and $\mathrm{H}_{3}-15$ to C-3' (Fig. 9). Accordingly, the planar structure of 5 was confirmed as shown in Fig. 9. The relative configuration was determined by the NOESY experiments. The key NOESY correlations of $\mathrm{H}-2 / \mathrm{H}_{3}-15^{\prime}, \mathrm{H}-2 / \mathrm{H}_{3}-14, \mathrm{H}-3^{\prime} / \mathrm{H}_{3}-15, \mathrm{H}-6 \mathrm{~b}^{\prime} / \mathrm{H}_{3}-15^{\prime}, \mathrm{H}-$ $6 \mathrm{~b}^{\prime} / \mathrm{H}_{3}-11^{\prime}$ and $\mathrm{H}-7^{\prime} / \mathrm{H}_{3}-10^{\prime}$ implied they were in the same side and assigned as $\beta$-oriented (Fig. 12). Furthermore, the key NOESY correlations of $\mathrm{H}-2 / \mathrm{H}-3^{\prime}$ indicated two guaiane units were endo-orientated. The absolute configuration of $\mathbf{5}$ was established from the CD spectrum and calculated ECD. The ECD spectra were calculated at the CAM-B3LYP/SVP level with the CPCM model in acetonitrile. The calculated ECD spectrum of 5 showed Cotton effects similar to those of the experimental results (Fig. S50†). Finally, the absolute configuration of $\mathbf{5}$ was assigned as $2 S, 4 R, 10 R, 3^{\prime} R, 4^{\prime} S, 7^{\prime} R, 10^{\prime} R$.

Xylopin F (6), was obtained as yellow oil. It gave the molecular formula $\mathrm{C}_{30} \mathrm{H}_{38} \mathrm{O}_{3}$, according to its positive HRESIMS at $\mathrm{m} / \mathrm{z}$ 469.2726 [M + Na $]^{+}$(calcd for $\mathrm{C}_{30} \mathrm{H}_{38} \mathrm{O}_{3} \mathrm{Na}^{+}$469.2713). The 1D NMR data of 6 displayed 30 carbon signals, including eight $\mathrm{CH}_{3}$, five $\mathrm{CH}_{2}$, four $\mathrm{CH}$ and 13 quaternary carbons, which were almost identical to those of 5 . The difference of 2 Da between the molecular weights of $\mathbf{5}$ and $\mathbf{6}$ suggested that $\mathbf{6}$ was dehydrogenation product of 5 . This was confirmed by the upfieldshifted $\mathrm{C}-7$ at $\delta_{\mathrm{C}} 134.2$ and $\mathrm{C}-11$ at $\delta_{\mathrm{C}}$ 141.3. The relative
Table $3{ }^{1} \mathrm{H}$ and ${ }^{13} \mathrm{C}$ NMR spectroscopic data of 5 and $6^{a}$

\begin{tabular}{|c|c|c|c|c|}
\hline \multirow[b]{2}{*}{ No. } & \multicolumn{2}{|l|}{6} & \multicolumn{2}{|l|}{7} \\
\hline & $\delta_{\mathrm{C}}$ & $\delta_{\mathrm{H}}$ & $\delta_{\mathrm{C}}$ & $\delta_{\mathrm{H}}$ \\
\hline 1 & $141.9 \mathrm{~s}$ & & $142.0 \mathrm{~s}$ & \\
\hline 2 & $58.1 \mathrm{~d}$ & $2.59 \mathrm{~s}$ & $58.1 \mathrm{~d}$ & $2.56 \mathrm{~s}$ \\
\hline 3 & $203.3 \mathrm{~s}$ & & $203.8 \mathrm{~s}$ & \\
\hline 4 & $59.3 \mathrm{~s}$ & & $58.9 \mathrm{~s}$ & \\
\hline 5 & $135.6 \mathrm{~s}$ & & $134.0 \mathrm{~s}$ & \\
\hline 6 & $26.5 \mathrm{t}$ & $\begin{array}{l}2.97 \mathrm{~d}(16.6) \\
2.80 \mathrm{~d}(16.6)\end{array}$ & $26.6 \mathrm{t}$ & $\begin{array}{l}3.32 \mathrm{~d}(17.0) \\
3.05 \mathrm{~d}(17.0)\end{array}$ \\
\hline 7 & $134.1 \mathrm{~s}$ & & $133.3 \mathrm{~s}$ & \\
\hline 8 & $213.3 \mathrm{~s}$ & & $202.9 \mathrm{~s}$ & \\
\hline 9 & $47.5 \mathrm{t}$ & $\begin{array}{l}2.79 \mathrm{~m} \\
2.32 \mathrm{dd}(11.5,4.7)\end{array}$ & $48.0 \mathrm{t}$ & $\begin{array}{l}3.00 \mathrm{~m} \\
2.44 \mathrm{dd}(13.2,6.6)\end{array}$ \\
\hline 10 & $33.9 \mathrm{~d}$ & $2.55 \mathrm{~m}$ & $33.9 \mathrm{~d}$ & $2.54 \mathrm{~m}$ \\
\hline 11 & $141.7 \mathrm{~s}$ & & $142.9 \mathrm{~s}$ & \\
\hline 12 & $23.1 \mathrm{q}$ & $1.97 \mathrm{~s}$ & $23.2 \mathrm{q}$ & $1.85 \mathrm{~s}$ \\
\hline 13 & $22.6 \mathrm{q}$ & $1.82 \mathrm{~s}$ & $23.1 \mathrm{q}$ & $2.03 \mathrm{~s}$ \\
\hline 14 & $20.7 \mathrm{q}$ & $1.07 \mathrm{~d}(6.8)$ & $19.3 \mathrm{q}$ & $1.06 \mathrm{~d}(6.9)$ \\
\hline 15 & $11.2 \mathrm{q}$ & $1.16 \mathrm{~s}$ & $24.1 \mathrm{q}$ & $1.24 \mathrm{~s}$ \\
\hline $1^{\prime}$ & $143.7 \mathrm{~s}$ & & $143.9 \mathrm{~s}$ & \\
\hline $2^{\prime}$ & $37.2 \mathrm{t}$ & $\begin{array}{l}2.54 \mathrm{ddt}(15.5,7.8,4.4) \\
1.49 \mathrm{~m}\end{array}$ & $37.4 \mathrm{t}$ & $\begin{array}{l}2.55 \mathrm{~d}(8.7,3.2) \\
1.42 \mathrm{~m}\end{array}$ \\
\hline $3^{\prime}$ & $49.8 \mathrm{~d}$ & $1.87 \mathrm{dd}(9.8,3.3)$ & $49.9 \mathrm{~d}$ & $1.88 \mathrm{~m}$ \\
\hline $4^{\prime}$ & $59.1 \mathrm{~s}$ & & $59.3 \mathrm{~s}$ & \\
\hline $5^{\prime}$ & $134.6 \mathrm{~s}$ & & $134.6 \mathrm{~s}$ & \\
\hline $6^{\prime}$ & $24.2 \mathrm{t}$ & $\begin{array}{l}2.48 \mathrm{~m} \\
2.21 \mathrm{~m}\end{array}$ & $26.7 \mathrm{t}$ & $\begin{array}{l}3.00 \mathrm{~d}(16.8) \\
2.78 \mathrm{~d}(16.8)\end{array}$ \\
\hline $\begin{array}{l}7^{\prime} \\
8^{\prime}\end{array}$ & $\begin{array}{l}58.3 \mathrm{~d} \\
204.7 \mathrm{~s}\end{array}$ & $2.15 \mathrm{~m}$ & $\begin{array}{l}134.2 \mathrm{~s} \\
204.5 \mathrm{~s}\end{array}$ & \\
\hline $9^{\prime}$ & $47.8 \mathrm{t}$ & $\begin{array}{l}3.07 \mathrm{~m} \\
2.44 \mathrm{~m}\end{array}$ & $48.1 \mathrm{t}$ & $\begin{array}{l}2.77 \mathrm{~m} \\
2.57 \mathrm{~m}\end{array}$ \\
\hline $10^{\prime}$ & $32.9 \mathrm{~d}$ & $2.43 \mathrm{~m}$ & $32.9 \mathrm{~d}$ & $2.29 \mathrm{~m}$ \\
\hline $11^{\prime}$ & $30.4 \mathrm{~d}$ & $1.86 \mathrm{~m}$ & $141.3 \mathrm{~s}$ & \\
\hline $12^{\prime}$ & $20.1 \mathrm{q}$ & $0.90 \mathrm{~d}(6.8)$ & $23.1 \mathrm{q}$ & $2.03 \mathrm{~s}$ \\
\hline $13^{\prime}$ & $19.2 \mathrm{q}$ & $0.91 \mathrm{~d}(6.8)$ & $23.0 \mathrm{q}$ & $1.99 \mathrm{~s}$ \\
\hline $14^{\prime}$ & $18.9 \mathrm{q}$ & $0.97 \mathrm{~d}(6.8)$ & $18.9 \mathrm{q}$ & $0.96 \mathrm{~d}(6.9)$ \\
\hline $15^{\prime}$ & $24.1 \mathrm{q}$ & $1.22 \mathrm{~s}$ & $11.2 \mathrm{q}$ & $1.23 \mathrm{~s}$ \\
\hline
\end{tabular}

${ }^{a} \delta$ in ppm; $J$ in $\mathrm{Hz}$ within parentheses; measured at $125 \mathrm{MHz}$ for ${ }^{13} \mathrm{C}$ NMR and $500 \mathrm{MHz}$ for ${ }^{1} \mathrm{H}$ NMR in chloroform- $d$.

configuration of $\mathbf{6}$ was in good agreement with $\mathbf{5}$ due to the same NOESY cross peak. Consequently, the absolute configuration of $\mathbf{6}$ was the same as that of $\mathbf{5}$ owing to the similar CD effects (Fig. S51 $\dagger$ ) and assigned as $2 S, 4 R, 10 R, 3^{\prime} R, 4^{\prime} S, 7^{\prime} R, 10^{\prime} R$.

Compounds 1-6 were evaluated their inhibitory activities on Wnt signaling pathway by EPT2-TGC cell model and zebrafish study. Among these compounds, only compound 6 had an indirect effect on Wnt signaling pathway. For EPT2-TGC cell

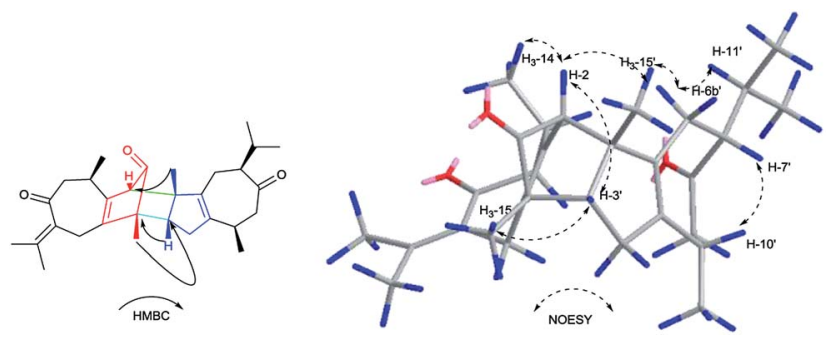

Fig. 9 Key HMBC, ${ }^{1} \mathrm{H}-{ }^{1} \mathrm{H}$ COSY and NOESY correlations of 5. 


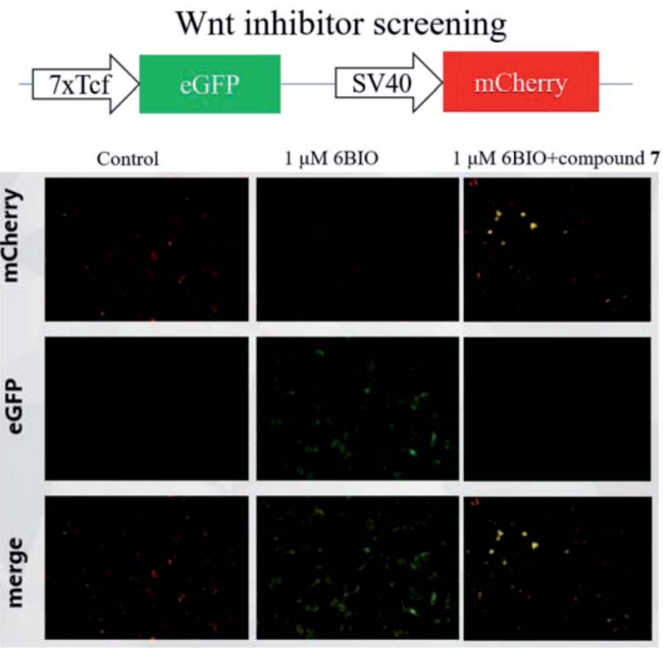

Fig. 10 EPT2-TGC cells were treated with compound $6(20 \mu \mathrm{M})$ for $24 \mathrm{~h}$ to detect TCF-GFP expression.

model, no significant Wnt pathway response was observed after administration of compound $6(10,20 \mu \mathrm{M})$ for $24 \mathrm{~h}$. However, combined with Wnt signaling activator 6BIO (GSK3 $\beta$ inhibitor), the intensity of green fluorescence was decreased, which indicated compound 6 could regulate the Wnt signaling pathway (Fig. 10). For zebrafish embryo model, the embryos were treated with compound 6 and 6BIO (GSK3 $\beta$ inhibitor) at $6 \mathrm{~h}$ postfertilization, for $48 \mathrm{~h}$. The embryo's eyeless phenomenon was observed at $24 \mathrm{hpf}$ (Fig. 11). The rescue rate in the $6 \mathrm{BIO}+$ compound $6(20 \mu \mathrm{M})$ group was higher than that in the $6 \mathrm{BIO}$ group suggested 6 could regulate the Wnt signaling pathway (Table S1†).

To evaluate the inhibitory effect on human cancer cells, DU145 cells was tested for their in vitro antitumor activity using CKK-8 assays. All of the compounds with various concentrations ranging from $0.9375 \mu \mathrm{M}$ to $30 \mu \mathrm{M}$ were assayed independently three times. Taxol was treated as the positive control $\left(\mathrm{IC}_{50}=\right.$ $1.66 \mu \mathrm{M})$. Compound 6 began to inhibit DU145 cells growth at $1.875 \mu \mathrm{M}\left(\mathrm{IC}_{50}=19.5 \mu \mathrm{M}\right)$, demonstrating that 6 displayed more potent cytotoxic activity on DU145 cells. However, the other compounds showed a weak inhibition against DU145 cells growth $\left(\mathrm{IC}_{50}>30 \mu \mathrm{M}\right)$. Cell apoptosis was determined using flow cytometry. As shown in Fig. 12A, DU145 cells in the G2 phase increased from $24.35 \%$ in control group to $27.76 \%, 31.57 \%$ and

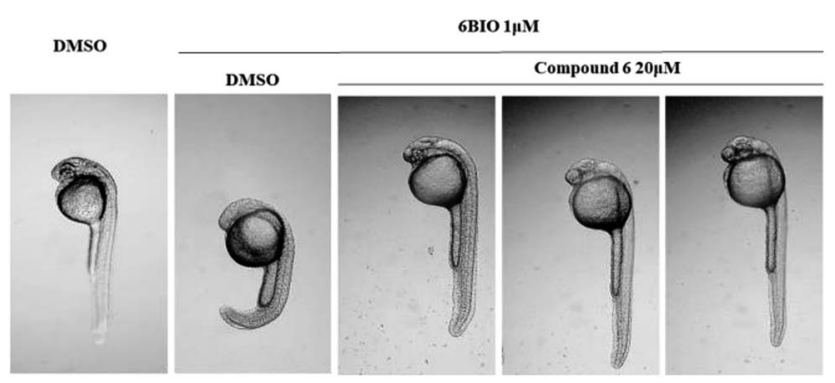

Fig. 11 Zebrafish embryos at $6 \mathrm{~h}$ post fertilization ( $6 \mathrm{hpf}$ ) were treated with $6 \mathrm{BIO}(1 \mu \mathrm{M})$ and compound $6(20 \mu \mathrm{M})$, and the eyeless phenotype was assessed $24 \mathrm{~h}$ later.

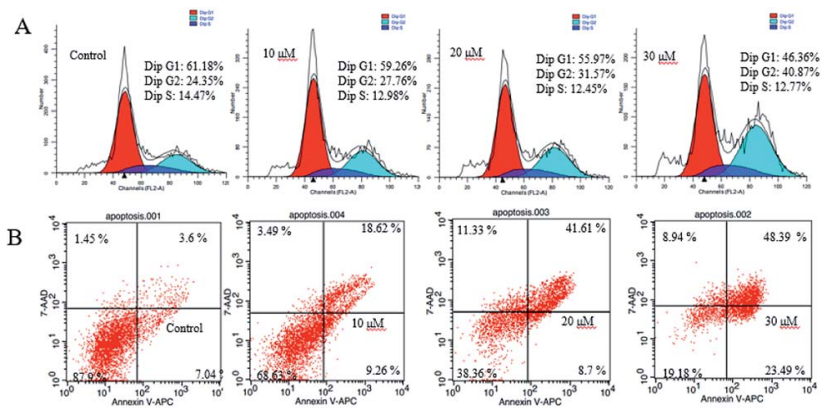

Fig. 12 (A) Cell cycle analysis of compound 6 in DU145 cells by flow cytometry. (B) Flow cytometry analysis of apoptosis induced by compound 6 in DU145 cells.

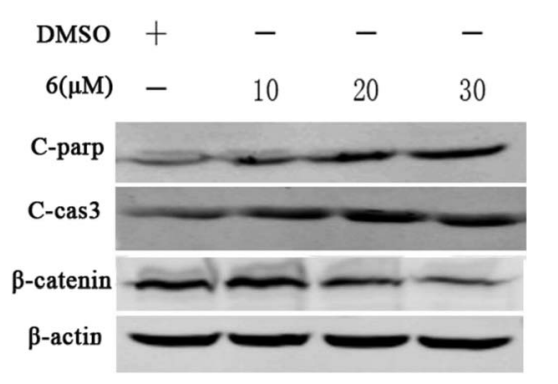

Fig. 13 Incubating with compound 6 for $24 \mathrm{~h}$, the level of protein Cparp, C-cas3, and $\beta$-catenin expression in DU145 cells was determined by western blot analysis. $\beta$-Actin was used as a control.

$40.87 \%$ in a concentration-dependent manner in DU145 cell lines indicated that compound 6 induced cell cycle arrest at the G2 phase. In addition, DU145 were treated with 10, 20 and 30 $\mu \mathrm{M}$ compound $\mathbf{6}$ for $24 \mathrm{~h}$, and the apoptotic rates increased to $27.88 \%, 42.48 \%$ and $67.88 \%$, respectively (vs. $10.63 \%$ in the control group) (Fig. 12B).

Owing to the above evidence, we tried to confirm whether compound 6 induced cell apoptosis via Wnt signaling pathway. Western blotting analysis revealed that the expression level $\beta$ catenin protein was down-regulated by compound 6 in a dosedependent manner. In addition, compound $\mathbf{6}$ significantly increased the apoptosis-related protein expression of cleavedparp and cleaved-caspase-3. Based on the results described above, compound 6 may induce DU145 cell apoptosis via the Wnt signaling pathway (Fig. 13).

\section{Conclusions}

In summary, six rare guaiane-type sesquiterpene dimers xylopins A-F (1-6) were isolated from the roots of $X$. vielana. Their structures were elucidated by extensive analyses of NMR spectroscopic data, X-ray analysis and CD spectrum. Compounds (16), connecting mode (C-2 to C-2 $2^{\prime}, \mathrm{C}-4$ to $\left.\mathrm{C}-3^{\prime}\right),\left(\mathrm{C}-2\right.$ to $\mathrm{C}-5^{\prime}, \mathrm{C}-4$ to $\left.\mathrm{C}-4^{\prime}\right)$, and ( $\mathrm{C}-2$ to $\mathrm{C}-4^{\prime}, \mathrm{C}-4$ to $\left.\mathrm{C}-3^{\prime}\right)$, featuring non-spiro ring system, which enriched the structural diversity of the genus Xylopia. In the biological screening conducted, compound $\mathbf{6}$ had shown the highest cytotoxicity among the tested compounds against DU145 cells with an $\mathrm{IC}_{50} 19.5 \mu \mathrm{M}$. 
Preliminary studies suggested compound 6 may induce apoptosis via the Wnt signaling pathway, which was due to an increase in the expression of cleaved-parp and cleaved-caspase3 with a concomitant decrease in the expression of $\beta$-catenin. Compound 6 may be useful for the development of a Wnt signaling inhibitor to combat cancers.

\section{Experimental}

\section{General experimental procedures}

$\mathrm{HSGF}_{254}$ silica gel plates (10-40 $\mu \mathrm{m}$, Yantai, China) were major used as TLC analysis. Silica gel (100-200 mesh, Yantai, China), silica gel $\mathrm{H}(10-40 \mu \mathrm{m}$, Qingdao, China) and Sephadex LH-20 (Pharmacia Co. Ltd.) were utilized as column chromatography materials. The Shimadzu LC-6AD series equipped with an SPD20 spectrophotometer using Shimadzu PRC-ODS EV0233 column was selected as the preparative HPLC. 1D and 2D NMR spectra were conducted on the Bruker Avance-500 NMR spectrometer, and chemical shifts are shown in d (ppm) with TMS as an internal reference and coupling constants were in Hz. ESIMS spectra were tested on Agilent LC/MSD Trap XCT spectrometer (Waters, USA) and HR-ESIMS on Q-TOF micro YA019 mass spectrometer (Waters, USA). Optical rotations were tested on the JASCO P-2000 polarimeter in $\mathrm{MeOH}$ at 20C. IR spectra were conducted on the Bruker FTIR Vector 22 spectrometer with $\mathrm{KBr}$ pellets.

\section{Plant material}

The roots of $X$. vielana were collected in Fangchenggang, Guangxi province, P. R. China, in December 2016. The identification of the plant material was authenticated by identified by Associate Prof. Zhang Daigui, College of Biology and Environment Sciences, Jishou University. A voucher specimen (No. 201611MBS) has been deposited in School of Pharmacy, Shanghai Jiao Tong University.

\section{Extraction and isolation}

Dried roots of $X$. vielana $(22.3 \mathrm{~kg})$ were powdered and extracted with $95 \%$ EtOH three times at room temperature and then evaporated under reduced pressure to give crude extract (764.1 g). The extract was further extracted with petroleum ether $(3 \mathrm{~L} \times$ $3)$, EtOAc $(3 \mathrm{~L} \times 3)$ to acquire two fractions. The PE fraction $(32.4 \mathrm{~g})$ was subjected to a silica gel (200-300 mesh) column chromatography, and eluted with a step gradient of PE-acetone $(100: 0$ to $0: 100 \mathrm{v} / \mathrm{v})$ to yield ten fractions (A-J). Fraction $\mathrm{G}(4.1$ g) was further isolated and eluted with PE-EtOAc $(50: 1$ to $10: 1, \mathrm{v} / \mathrm{v})$ then got five fractions (G-1-G-5). Fraction G-1 (300.0 $\mathrm{mg})$ was purified by preparative HPLC $\left(\mathrm{MeOH}: \mathrm{H}_{2} \mathrm{O}, 65: 35\right)$ to yield $1\left(t_{\mathrm{R}}=28 \mathrm{~min}, 18.2 \mathrm{mg}\right)$ and $2\left(t_{\mathrm{R}}=54 \mathrm{~min}, 16.6 \mathrm{mg}\right)$. Fraction G-3 $(1.0 \mathrm{~g})$ was subjected to Sephadex IL-20 eluting with (DCM : MeOH, 30:1), to obtain four fractions (G-3.1-3.4). Compound $4\left(t_{\mathrm{R}}=36 \mathrm{~min}, 18.2 \mathrm{mg}\right)$ were acquired from fraction G-3.2 $(280.0 \mathrm{mg})$ using preparative HPLC $\left(\mathrm{MeOH}: \mathrm{H}_{2} \mathrm{O}, 70: 30\right)$. Compound $5(18.2 \mathrm{mg})$ was obtained from fraction G-3.3 (120.0 $\mathrm{mg}$ ) by Preparative TLC (DCM : MeOH, $50: 1)$. Fraction F (4.6 g) was chromatographed on silica gel H (400-500 mesh), eluting with PE-EtOAc (50:1 to $10: 1$ ), to give five subfraction (F-1-F5). Fraction F-2 (610.9 mg) was further purified by preparative HPLC to yield $6(15.2 \mathrm{mg})$ and $3(8.2 \mathrm{mg})$.

\section{Details of new compounds}

Xylopin A (1). Colorless prismatic crystal; $[\alpha]_{\mathrm{D}}^{20}-16.5$ (c 0.10 $\mathrm{CH}_{2} \mathrm{Cl}_{2}$ ); IR (KBr) $\nu_{\max } 3446,2956,2911,2869,2850,1688,1462$, 1377, 1026, $668 \mathrm{~cm}^{-1}$; for ${ }^{1} \mathrm{H}$-NMR and ${ }^{13} \mathrm{C}-\mathrm{NMR}$ spectroscopic data, see Table 1; HRESIMS (positive): $m / z 513.2977[\mathrm{M}+\mathrm{Na}]^{+}$ (calcd for 513.2975).

Xylopin B (2). Needle crystals; $[\alpha]_{\mathrm{D}}^{20}-23.2\left(\mathrm{c} 0.10 \mathrm{CH}_{2} \mathrm{Cl}_{2}\right)$; IR (KBr) $\nu_{\max } 3445,2957,2926,2871,1697,1632,1376,1265$, $1160 \mathrm{~cm}^{-1}$; for ${ }^{1} \mathrm{H}$-NMR and ${ }^{13} \mathrm{C}-\mathrm{NMR}$ spectroscopic data, see Table 1; HRESIMS (positive): $m / z 545.2876[\mathrm{M}+\mathrm{Na}]^{+}$(calcd for 545.2874).

Xylopin C (3). Colorless crystal; $[\alpha]_{\mathrm{D}}^{20}-41.3\left(\mathrm{c} 0.11 \mathrm{CH}_{2} \mathrm{Cl}_{2}\right)$; IR (KBr) $\nu_{\max } 2956,1674,1456,1375,1024 \mathrm{~cm}^{-1}$; CD (c $0.9 \times$ $10^{-5} \mathrm{M}, \mathrm{CH}_{2} \mathrm{Cl}_{2}$ ), $\Delta \varepsilon(\mathrm{nm}):+98.5$ (233), -85.6 (255); for ${ }^{1} \mathrm{H}-\mathrm{NMR}$ and ${ }^{13} \mathrm{C}-\mathrm{NMR}$ spectroscopic data, see Table 2; HRESIMS (positive): $m / z 515.2418[\mathrm{M}+\mathrm{Na}]^{+}$(calcd for 515.2404).

Xylopin D (4). Yellow oil; $[\alpha]_{\mathrm{D}}^{20}-65.3\left(\mathrm{c} 0.11 \mathrm{CH}_{2} \mathrm{Cl}_{2}\right)$; IR (KBr) $\nu_{\max } 3445,2911,2852,1699,1651,1457,1379,1120,669 \mathrm{~cm}^{-1}$; $\mathrm{CD}\left(\mathrm{c} 6.0 \times 10^{-5} \mathrm{M}, \mathrm{CH}_{2} \mathrm{Cl}_{2}\right), \Delta \varepsilon(\mathrm{nm}):+60.3(231),-39.8(250)$; for ${ }^{1} \mathrm{H}$-NMR and ${ }^{13} \mathrm{C}-\mathrm{NMR}$ spectroscopic data, see Table 2; HRESIMS (positive): $m / z 485.2674[\mathrm{M}+\mathrm{Na}]^{+}$(calcd for 485.2662).

Xylopin E (5). Yellow oil; $[\alpha]_{\mathrm{D}}^{20}-30.3\left(c 0.10 \mathrm{CH}_{2} \mathrm{Cl}_{2}\right)$; IR $(\mathrm{KBr})$ $\nu_{\max } 3445,2957,2866,2850,1703,1680,1458,688 \mathrm{~cm}^{-1}$; CD (c $\left.1.2 \times 10^{-5} \mathrm{M}, \mathrm{CH}_{2} \mathrm{Cl}_{2}\right), \Delta \varepsilon(\mathrm{nm}):+14.7(259),-13.8(301) ;$ for ${ }^{1} \mathrm{H}-$ NMR and ${ }^{13} \mathrm{C}-\mathrm{NMR}$ spectroscopic data, see Table 3; HRESIMS (positive): $m / z 471.2880[\mathrm{M}+\mathrm{Na}]^{+}$(calcd for 471.2870 ).

Xylopin F (6). Yellow oil; $[\alpha]_{\mathrm{D}}^{20}-34.3\left(\mathrm{c} 0.10 \mathrm{CH}_{2} \mathrm{Cl}_{2}\right)$; IR (KBr) $\nu_{\max } 3445,2957,2869,2850,1699,1456,1378,1170,699 \mathrm{~cm}^{-1}$; $\mathrm{CD}\left(\mathrm{c} 1.0 \times 10^{-5} \mathrm{M}, \mathrm{CH}_{2} \mathrm{Cl}_{2}\right), \Delta \varepsilon(\mathrm{nm}):+23.3$ (235), -28.3 (287); for ${ }^{1} \mathrm{H}$-NMR and ${ }^{13} \mathrm{C}-\mathrm{NMR}$ spectroscopic data, see Table 3; HRESIMS (positive): $m / z 543.2722[\mathrm{M}+\mathrm{Na}]^{+}$(calcd for 543.2717).

\section{EPT2-TGC cell model}

Prostate EPT2 cells were established by X. K. and K.-H. K laboratory (Shanghai University of Traditional Chinese Medicine). Lentiviral vector 7TGC together with packaging plasmids pMD2.G and pCMVR8.74 was co-transfected into 293FT cells with Lipofectamine 3000 in order to build the stable cell lines containing Wnt reporters. ${ }^{19}$ After $16 \mathrm{~h}$, the culture medium was replaced with medium for cells of interest. $24 \mathrm{~h}$ later, the culture medium was filtered through a $0.45 \mu \mathrm{m}$ filter and incubated with cells for $24 \mathrm{~h}$. The expression of eGFP and mCherry in transduced cells was assessed by fluorescence microscopy and FACS (FACSAria; BD Biosciences). EPT2-TGC cells were seeds in 96-well plates at $8 \times 10^{3}$ cell per well at $37^{\circ} \mathrm{C}$ under a humidified atmosphere of $5 \% \mathrm{CO}_{2}$. After $12 \mathrm{~h}$, the supernatant was discarded, and the cells were treated with different compounds $(10 \mu \mathrm{M})$ and 6BIO (GSK3 $\beta$ inhibitor) for $24 \mathrm{~h}$.

\section{Zebrafish study}

Wild type zebrafish were raised and maintained under standard conditions and treated in accordance with the guidance 
suggestions for the Care and Use of Laboratory Animals formulated by the Ministry of Science and Technology of China and approved by the Committee on the Ethics of Animal Experiments of East China Normal University (approval no.: F20140101). For the eyeless phenotype rescue assay, embryos at $6 \mathrm{hpf}$ were cultured in 48-well plates (10 embryos per well) at $28.5{ }^{\circ} \mathrm{C}$. The embryos were treated with the isolated compounds and $6 \mathrm{BIO}$ (GSK3 $\beta$ inhibitor) at $6 \mathrm{~h}$ post-fertilization, for $48 \mathrm{~h}$. The egg water solution was used as blank control group, and the model control group contained $0.8 \mu \mathrm{M}$ 6BIO. The eye development (two eyes, one eye, or no eye) was visualized using the fluorescent microscope to assess the drug sensitivity of Wnt signaling pathway. ${ }^{20}$

\section{Cell culture}

Human prostate cancer cell line (DU145) was cultured in media containing $10 \% \mathrm{FBS}, 100$ units per $\mathrm{mL}$ penicillin, $100 \mathrm{mg} \mathrm{mL}^{-1}$ streptomycin at $37^{\circ} \mathrm{C}$ in a humidified incubator in the presence of $5 \% \mathrm{CO}_{2}$.

\section{Cytotoxic assay}

Cytotoxic assay was measured using a Cell Counting Kit-8 (CCK8) (Dojindo, Kumamoto, Japan) according to the manufacturer's instructions. In brief, the cells $\left(1.0 \times 10^{4}\right.$ cells per well $)$ were seeded in 96-well microplates for $24 \mathrm{~h}$, added with different concentrations of compounds or $0.1 \%$ DMSO as vehicle control. After incubation $24 \mathrm{~h}, 2 \mu \mathrm{L}$ of CCK- 8 solution was added to each well for additional $1 \mathrm{~h}$ incubation before the absorbance was measured at $450 \mathrm{~nm}$ by an epoch microplate spectrophotometer.

\section{Flow cytometry analysis}

DU145 cells were seeded in 6-well plates $\left(1.0 \times 10^{6}\right.$ cells per well) for $24 \mathrm{~h}$ and then treated with compounds at dose-related concentrations or DMSO for $24 \mathrm{~h}$. The treated cells were stained using Annexin V-APC/7-AAD apoptosis detection kit (MultiSciences Biotech, CA) and the cell cycle kit (MultiSciences Biotech, CA) according to the manufacturer's instructions. After incubation at room temperature for $15 \mathrm{~min}$ in the dark, the apoptosis and the cell cycle were immediately analyzed by flow cytometry (Becton Dickinson FACS Vantage SE, San Jose, CA, USA). ${ }^{21}$

\section{Western blot analysis}

DU145 were treated with 6 for 24 h, washed twice with PBS, and lysed in lysis buffer (NP40: PMSF = 100:1 Promega, USA) for $30 \mathrm{~min}$ on ice. The concentration of protein in the supernatant fractions were determined using the Pierce ${ }^{\mathrm{TM}}$ BCA Protein Assay Kit in the light of the manufacturer's instructions. Equal amounts of protein were electrophoresed using 10\% SDSpolyacrylamide gel and then transferred to PVDF membranes (Bio-Rad). After blocking with 5\% (w/v) non-fat milk for $1 \mathrm{~h}$ at RT and washing with Tris-buffered saline-Tween solution (TBST), the membranes were incubated with primary antibody for $\beta$-catenin (S33/37/T41) (rabbit, 1 : 500, Cell Signaling) and or $\beta$-actin (mouse, $1: 10$ 000, Sigma) overnight at $4{ }^{\circ} \mathrm{C}$, followed by incubation with a anti-rabbit or a anti-mouse second antibodies for $1.5 \mathrm{~h}$ at RT. The membranes were washed three times with PBST and then were visualized using the Odyssey Infrared Imaging System (LI-COR, Biosciences). The cleaved parp (Lot 5625) and cleaved caspase-3 (Lot 9664) antibodies purchased from Cell Signaling Technology company.

\section{X-ray crystallography}

Crystallographic data of 1. Monoclinic crystal of $\mathrm{C}_{32} \mathrm{H}_{42} \mathrm{O}_{4}, M$ $=490.66$, space group $P 2_{1}$; cell dimensions $a=10.6277(9) \AA$, alpha $=90$ deg. $b=9.1356(7) \AA$, beta $=104.143(5)$ deg. $c=$ 14.4964(13) ̊̊, gamma = $90 \mathrm{deg}$; volume 1364.8(2) $\AA^{3} ; Z=2$, calculated density $1.196 \mathrm{mg} \mathrm{m}^{-3}$; crystal size $0.05 \times 0.04 \times 0.03$ $\mathrm{mm}$; absorption coefficient $0.604 \mathrm{~mm}^{-1}, F(000)=534$, theta range for data collection 5.801 to $65.098 \mathrm{deg}$; final $R$ indices [ $I>$ $2 \operatorname{sigma}(I)] R_{1}=0.0554, \mathrm{w} R_{2}=0.1370 ; R$ indices (all data) $R_{1}=$ $0.0634, \mathrm{w} R_{2}=0.1431$; wavelength $1.54178 \AA$, temperature $173(2)$ K.

Crystallographic data of 2. Orthorhombic crystal of $\mathrm{C}_{32} \mathrm{H}_{42} \mathrm{O}_{6}, M=522.65$, space group $P 2{ }_{1} 2_{1} 2_{1}$; cell dimensions $a=$ 9.7328(4) $\mathrm{A}$, alpha $=90$ deg. $b=16.8465(9) \AA$, beta $=90$ deg. $c=$ 18.1390(10) $\AA$, gamma = $90 \mathrm{deg}$; volume 2974.1(3) $\AA^{3} ; Z=4$, calculated density $1.165 \mathrm{mg} \mathrm{m}^{-3}$; crystal size $0.05 \times 0.04 \times 0.03$ $\mathrm{mm}$; absorption coefficient $0.636 \mathrm{~mm}^{-1}, F(000)=1124$, theta range for data collection 3.581 to $63.608 \mathrm{deg}$; final $R$ indices [ $I>$ $2 \operatorname{sigma}(I)] R_{1}=0.0948, \mathrm{w} R_{2}=0.2535 ; R$ indices (all data) $R_{1}=$ $0.1250, \mathrm{w} R_{2}=0.2836$; wavelength $1.54178 \AA$ A, temperature $173(2)$ K.

Crystallographic data of 3. Orthorhombic crystal of $\mathrm{C}_{30} \mathrm{H}_{36} \mathrm{O}_{6}, M=492.59$, space group $P 2{ }_{1} 2_{1} 2_{1}$; cell dimensions $a=$ 10.7928(4) $\AA$, alpha = 90 deg. $b=10.793 \AA$, beta $=90$ deg. $c=$ 23.0110(10) $\AA$, gamma = 90 deg; volume 2680.43(15) $\AA^{3} ; Z=4$, calculated density $1.221 \mathrm{mg} \mathrm{m}^{-3}$; crystal size $0.180 \times 0.160 \times$ $0.140 \mathrm{~mm}$; absorption coefficient $0.678 \mathrm{~mm}^{-1}, F(000)=1056$, theta range for data collection 3.842 to $68.642 \mathrm{deg}$; final $R$ indices $[I>2 \operatorname{sigma}(I)] R_{1}=0.0371, \mathrm{w} R_{2}=0.0924 ; R$ indices (all data) $R_{1}=0.0527, \mathrm{w} R_{2}=0.0985$; wavelength $1.54178 \AA$, temperature 296(2) K.

Crystallographic data for compounds 1-3 have been deposited at the Cambridge Crystallographic Data Centre with the deposition numbers CCDC 1834120, 1840033, and 1841412 respectively.

\section{Computational methods}

Conformational searches were performed by the MOE software using the MMFF94 force field. The obtained conformers were used for geometry reoptimizations at the B3LYP/6-31G(d,p) level in the Gaussian 09 package. The ECD spectra for the optimized conformers were calculated at the CAMB3LYP/SVP level with a CPCM solvent model in acetonitrile, and the calculated ECD spectra of different conformers were simulated with a halfbandwidth of $0.3-0.4 \mathrm{eV}$. The ECD curves were extracted by SpecDis 1.6 software. $^{22,23}$ The overall ECD curves of all the compounds were weighted by Boltzmann distribution after UV correction. 


\section{Conflicts of interest}

There are no conflicts to declare.

\section{Acknowledgements}

The work was supported by Professor of Chang Jiang Scholars Program, NSFCs (81230090, 81520108030, 21472238), Shanghai Engineering Research Center for the Preparation of Bioactive Natural Products (16DZ2280200), the Scientific Foundation of Shanghai China (12401900801, 13401900103, 13401900101), the National Key Research and Development Program of China (2017YFC1700200). We are grateful to Prof. Yuanqiang Guo from Nankai University for calculated electronic circular dichroism spectra, Xisong Ke from Shanghai University of Traditional Chinese Medicine for Wnt signaling pathway screening and Zhenyu Du from School of Life Sciences, East China Normal University for zebrafish mode. We thank Prof. Lingling Li from the Instrumental Analysis Center of Shanghai Jiao Tong University for X-ray crystallographic analysis.

\section{Notes and references}

1 C. Kamperdick, N. M. Phuong, G. Adam and T. Van Sung, Phytochemistry, 2003, 64, 811-816.

2 I. C. Moreira, J. H. G. Lago and N. F. Roque, Alkaloid, Biochem. Syst. Ecol., 2003, 31, 535-537.

3 N. K. Nik Abdullah Zawawi, N. Ahmat, R. Ahmad, F. M. Jaafar and N. A. Ghani, Biochem. Syst. Ecol., 2012, 43, 7-9.

4 I. C. Moreira, J. H. G. Lago and N. F. Roque, Biochem. Syst. Ecol., 2005, 33, 948-951.

5 Y. Nishiyama, M. Moriyasu, M. Ichimaru, K. Iwasa, A. Kato, S. G. Mathenge, P. B. Chalo Mutiso and F. D. Juma, Phytochemistry, 2004, 65, 939-944.

6 Y. G. Guo, Y. H. Ding, G. J. Wu, S. L. Zhu, Y. F. Sun, S. K. Yan, F. Qian, H. Z. Jin and W. D. Zhang, Fitoterapia, 2018, 127, 96100.

7 E. V. Costa, L. M. Dutra, A. Nepel and A. Barison, Biochem. Syst. Ecol., 2013, 51, 331-334.

8 Y. Nishiyama, M. Moriyasu, M. Ichimaru, K. Iwasa, A. Kato, S. G. Mathenge, P. B. Chalo Mutiso and F. D. Juma, Phytochemistry, 2006, 67, 2671-2675.
9 C. M. Hasan, T. M. Healey and P. G. Waterman, Phytochemistry, 1982, 21, 1365-1368.

10 J. A. Takahashi, M. A. D. Boaventura, J. de Carvalho Bayma and O. Alaíde B, Frutoic acid, Phytochemistry, 1995, 40, 607-609.

11 I. C. Moreira, N. F. Roque and J. H. G. Lago, Biochem. Syst. Ecol., 2006, 34, 833-837.

12 C. M. Hasan, T. M. Healey and P. G. Waterman, Phytochemistry, 1985, 24, 192-194.

13 D. Martins, L. Hamerski, S. A. V. Alvarenga and N. d. F. Roque, Phytochemistry, 1999, 51, 813-817.

14 Y. G. Xie, Y. G. Guo, G. J. Wu, S. L. Zhu, T. F. Cheng, Y. Zhang, S. K. Yan, H. Z. Jin and W. D. Zhang, Org. Biomol. Chem., 2018, 16, 8408-8412.

15 Y. L. Zhang, X. W. Zhou, X. B. Wang, L. Wu, M. H. Yang, J. Luo, Y. Yin, J. G. Luo and L. Y. Kong, Org. Lett., 2017, 19, 3013-3016.

16 V. Kuete, L. P. Sandjo, A. T. Mbaveng, M. Zeino and T. Efferth, Phytomedicine, 2015, 22, 1247-1254.

17 R. P. C. Ferraz, G. M. B. Cardoso, T. B. da Silva, J. Fontes, A. Prata, A. A. Carvalho, M. O. Moraes, C. Pessoa, E. V. Costa and D. P. Bezerra, Food Chem., 2013, 141, 196200.

18 T. Shono, N. Ishikawa, K. Toume, M. A. Arai, H. Masu, T. Koyano, T. Kowithayakorn and M. Ishibashi, J. Nat. Prod., 2016, 79, 2083-2088.

19 Y. Qu, A. M. Oyan, R. Liu, Y. Hua, J. Zhang, R. Hovland, M. Popa, X. Liu, K. A. Brokstad and R. Simon, Cancer Res., 2013, 73, 7090-7100.

20 Y. Qu, N. Gharbi, X. Yuan, J. R. Olsen, P. Blicher, B. Dalhus, K. A. Brokstad, B. Lin, A. M. Oyan, W. Zhang, K. H. Kalland and X. Ke, Proc. Natl. Acad. Sci. U. S. A., 2016, 113, 9339-9344.

21 H. Chen, B. Y. Chen, C. T. Liu, Z. Zhao, W. H. Shao, H. Yuan, K. J. Bi, J. Y. Liu, Q. Y. Sun and W. D. Zhang, Eur. J. Med. Chem., 2014, 83, 307-316.

22 J. Xu, Q. Zhang, M. Wang, Q. Ren, Y. Sun, D. Q. Jin, C. Xie, H. Chen, Y. Ohizumi and Y. Guo, J. Nat. Prod., 2014, 77, 2182-2189.

23 J. Xu, Y. Sun, M. Wang, Q. Ren, S. Li, H. Wang, X. Sun, D. Q. Jin, H. Sun, Y. Ohizumi and Y. Guo, J. Nat. Prod., 2015, 78, 1563-1569. 